Hugoye: Journal of Syriac Studies, Vol. 14.2, 225-247

(C) 2011 by Beth Mardutho: The Syriac Institute and Gorgias Press

\title{
'CAST OUT HAGAR AND ISMAEL HER SON FROM ME' TEXT AND INTERTEXT IN EUTYCHIUS OF ALEXANDRIA'S ANNALS
}

\author{
JUAN PEDRO MONFERRER-SALA \\ UNIVERSITY OF CORDOBA (SPAIN)
}

\section{INTRODUCTION}

Sa īd ibn Bațrīq was born in Cairo in 877 A.D. He became patriarch of Alexandria in 933 A.D. and remained so until his death in 940 A.D. under his throne name Eutychius. ${ }^{1}$ Well-learned in the knowledge of the so-called sciences of the Christians, ${ }^{2}$ he was also a practising physician and a chronographer as well. His main work, which has survived under the title Kitäb al-ta' rikeh al-majmü' 'alä altahqiq wa-l-tasdiq, "The book of history compiled on the basis of

${ }^{1}$ Georg Graf, Geschichte der christlichen arabischen Literatur, «Studi e Testi» 133, Modena, 1996 (= Città del Vaticano, 1947]), II, pp. 32-38. See also Joseph Nasrallah, Histoire du mouvement littéraire dans l'église melchite du $V^{e}$ an $X X^{e}$ siècle. Contribution à l'étude de la littérature arabe chrétienne II/2, Louvain-Paris: Peeters, 1988, pp. 23-34, and Ğurğ Šihātah Qanawātī [= G. Anawati], al-Masihizyah wa-l-hadārah al-arabiyyah, Cairo: Dār alTaqāfah, 1992, 2nd ed., pp. 245-246.

2 Ibn Abī Ușaybi'ah, 'Uyūn al-anbà fì tabaqāt al-ațibbäà, ed. Nizār Riḍā, Beirut: Dār Maktabat al-Hayāh, 1965, pp. 545-546.

3 Eutychii Patriarchae Alexandrini Annales, edited by L. Cheikho et al., Corpus Scriptorum Christianorum Orientalium 50-51-Scriptores 
verification and authentication", although he entitled his work as Kitāb naẓm al-jawāhir or "The string of pearls", "being know like Eutychius of Alexandria's Annals.

The Annals were not written in Greek, but in Arabic language, since in that period the new lingua franca ${ }^{5}$ became the tongue of most Christians in Egypt, who had already forgotten Coptic and Greek. This is not surprising at all, because the Melkites in Egypt, although in Syria as well, needed texts for their everyday life, as well as for disputing the Muslim attacks against the Christian faith in the new lingua franca, Arabic.

The Kitāb nazm al-jawāhir or Annals is Eutychius' most enduring work that was polished by later compilers. The first edition was done by Pococke, ${ }^{6}$ together with a Latin translation which was later emended by Ibrāhīm al-Hāqilī. ${ }^{7}$ In the early 20th century F. Cheikho reedited Pococke's edition adding textual variants provided by other MSS. In the second half of the $20^{\text {th }}$ century a

Arabici 6-7, 2 vols., Louvain: Secrétariat du CorpusSCO, 1960, 1962 (= Beirut-Paris-Leipzig: E Typographeo Catholico-Carolus Poussielgue-Otto Harrassowitz, 1906, 1909). [Henceforth: Annales]. An Italian translation is due to Bartolomeo Pirone: Gli Annali, introduzione, traduzione e note, Studia Orientalia Christiana Monographiae 1, Cairo: Franciscan Center of Christian Oriental Studies, 1987.

4 Annales, I, p. 3.

${ }^{5}$ Joshua Blau, "A Melkite Arabic lingua franca from the second half of the First Millennium", Bulletin of the School of Oriental and African Studies 57 (1994), pp. 14-16.

6 Contextio Gemmarum sive Eutychii Patriarchae Alexandrini Annales, J. Seldeni, E. Pocockio, 2 vols., Oxford, 1658-1659; J.-P. Migne (ed.), Patrologiae cursus completus, omnium SS. patrum, doctorum scriptorumque ecclesiasticorum. Series graeca [= PG], Paris, 1856-61 (1st series), 1857-66 ( $2^{\text {nd }}$ series), CXI, cols. 907-1156 with a preface by J. Selden in cols. 889894. See also a partial translation in Joannes Seldenus, Eutychii Aegypti patriarchae orthodoxorum Alexandrini, scriptoris ut in Oriente admodum vetusti ac illustris, ita in Occidente tum paucissimis visi, tum perraro auditi, Ecclesiae suae Origines, Oxford, 1642.

${ }^{7}$ Abraham Echellensis, Eutychius patriarca Alexandrinus vindicatus et suis restitutus orientalibus, Rome, 1661. The translation is reproduced in M.-J. Migne (ed.), PG, CXI, cols. 903-906, together with Selden's version. 
new edition by M. Breydy based on the MS 'Sin. ar. 582' appeared. ${ }^{8}$ He established the distinction between what he has called the 'Antiochene' and 'Alexandrian' recensions.' Breydy's edition and translation contains an original recension of the tenth century Kitäb naz̧m al-jawāhir, a text with interesting textual variants and omissions $^{10}$ that present more exact readings than Cheikho's edition. ${ }^{11}$

Eutychius' work is, in essence, an universal chronicle beginning with the creation of the world up to the year $326 \mathrm{H} / 937-8 \mathrm{CE}$, in the caliphate of al-Raḍi bi-l-Lāh (322-329 H/934-940 CE).12 The text, which has survived in two recensions contains plenty of information about the history of Syria, Palestine and Egypt from the seventh century up to the early tenth century, turned into an

${ }^{8}$ Das Annalenwerk des Eutychius von Alexandrien. Ausgewählte Geschichten und Legenden kompiliert von Sa’id Ibn Batriq um 935 A.D., ed. Michael Breydy «Corpus Scriptorum Christianorum Orientalium» 471-472—Scriptores Arabici 44-45, 2 vols., Louvain: Peeters, 1985.

9 For a discusión of Breydy's proposals, see Sidney H. Griffith, "Apologetics and Historiography in the Annals of Eutychius of Alexandria: Christian Self-Definition in the World of Islam", in Rifaat Ebied \& Herman Teule (eds.), Studies on the Christian Arabic Heritage in Honour of Father Prof. Dr. Samir Khalil Samir S.I. at the Occasionof his Sixty-Fifth Birthday, Leuven-Paris-Dudley (Ma): Peeters, 2004, pp. 78-89.

10 M. Breydy, "Über die älteste Vorlage der 'Annales Eutychii' in der identifizierten Handschrift Sinait. Arab. 580”, Oriens Christianus 59 (1975), pp. 165-168. See for a whole consideration M. Breydy, Études sur Sa'id ibn Batriq et ses sources, «Corpus Scriptorum Christianorum Orientalium» 450 Subsidia 69 (Louvain: Peeters, 1983). A textual analysis of a fragment in Juan Pedro Monferrer-Sala, "A propósito de un fragmento del s. XVII de los "Anales" de Eutiquio de Alejandría", Archivo Teológico Granadino 63 (2000), pp. 161-189, especially pp. 169-184.

11 M. Breydy, "Mamila ou Maqella? La prise de Jérusalem et ses conséquences (614 A.D.) selon la recensión alexandrine des Annales d'Eutychès", Oriens Christianus 65 (1981), pp. 62-86. Cf. P. Schreiner, "Fragments d'une paraphrase grecque des Annales d'Eutyches d'Alexandrie”, Orientalia Cristiana Periodica 37 (1971), pp. 384-390.

${ }^{12}$ For a resumé of its contents, see Sidney H. Griffith, "Apologetics and Historiography in the Annals of Eutychius of Alexandria: Christian Self-Definition in the World of Islam", in Rifaat Ebied \& Herman Teule (eds.), Studies on the Christian Arabic Heritage, pp. 65-89. 
essential source for later historians. The work is mainly based on Byzantine chronographies and it is riddled with traditional legends and derived numerous benefits from the profane and ecclesiastical history tractates, the biblical texts, ${ }^{13}$ the Muslim traditionalists, ${ }^{14}$ and from the kinds of documents to which later historians had no access. ${ }^{15}$

According to this, a close examination of the biblical acounts in Eutychius' Annals reveals a diversity and complex use of sources that were available to the author directly or through an intermediate source he had relied on. ${ }^{16}$ This is the case of the following extract we are dealing with in the following lines. Eutychius' narrative on the expulsion of Hagar and Ismael runs as follows: $:^{17}$

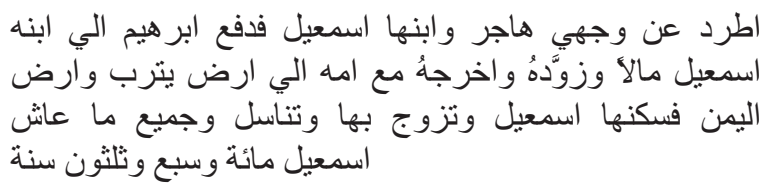

13 Gérard Troupeau, "La littératue arabe chrétienne du $\mathrm{X}^{\mathrm{e}}$ au XII" siècle", in G. Troupeau, Études sur le christianisme arabe au Moyen Âge, Collected Studies Series 515, Aldershot, Hamshire: Variorum, 1995, I, pp. 16-17; Sidney H. Griffith, "Eutychius of Alexandria on the Emperor Theophilus and Inconoclasm in Byzantium: a $10^{\text {th }}$-century moment in Christian apologetics in Arabic", Byzantion 52 (1982), pp. 157-158.

14 M. Breydy, "La chronique arabe de l'Egypte. Un fragment du traditionniste Uthmān ibn Ṣaliḥ identifié dans les Annales d'Eutychios d'Alexandrie", Parole de l'Orient VIII (1977-78), pp. 379-396.

15 Samir Khalil Samir, "Christian Arabic literature in the 'Abbasid period", in M.J.L. Young-J.D. Latham \& R.B. Serjeant (eds.), The Cambridge History of the Arabic Literature: Religion, learning and science in the 'Abbasid period, Cambridge: Cambridge University Press, 1990, pp. 456457.

16 See some examples related to Egypt in J.P. Monferrer-Sala, "Egyptian major issues in Eutychius of Alexandria's Kitāb nażm al-jawāhir", in J.P. Monferrer-Sala_-Vassilios Christides-Theodor Papadopoullos (eds.), East and West. Essays on Byzantine and Arab worlds in the Middle Ages, Piscataway, New Jersey: Gorgias Press, 2009, pp. 201-223.

17 Annales, p. 22. Cf. the Italian translation by B. Pirone, Gli Annali, p. 47. 


\begin{abstract}
"Cast out of my face Hagar and her son Ismael. And Abraham gave to his son Ismael goods and provisioned him and sent him with his mother to the land of Yathrib and the land of Yemen. And Ismael dwelled and married there and he multiplied. All what Ismael lived was one hundred and thirty seven years"
\end{abstract}

A cursory examination of the fragment indicates that Eutychius has transmitted a text with a dual structure: while the textual referent of the first part is Gn 21:10.14, the second part (akbraja-bu ila ard Yatrib ... wa-talatunna sanah) draws on a number of extrabiblical textual Vorlagen. In order to analyse these two units separately, we shall refer to the first part of the fragment as the "text" and the second part as the "intertext", based on Genette's definition of intertextuality as a relationship of co-presence between two or more texts, i.e. the actual presence of one text within another. ${ }^{18}$

\title{
1. THE 'TEXT' AND ITS NARRATIVE PARADIGM
}

It seems wholly reasonable to assert that Eutychius takes as the narrative framework for the 'text' the biblical account in Gn 21:14 16. ${ }^{19}$ In these two verses, the banishing of Hagar and Ismael ${ }^{20}$ forms part of a narrative segment that testifies to its author's perfect mastery of storytelling technique; the descriptive element plays a key role in the story, which can be labelled as what has come to be called "biblical prose narrative". ${ }^{21}$ The author charts all the preparations for departure, skilfully selecting the elements appropriate to the initial event as prompted by the plot. The components of the incipit are few, but always precise: timing, provisioning, departure. The act is structured as a triple sequence,

18 G. Genette, Palimsestes. La littérature au second degré, Paris, 1982, p. 8.

19 For a framework study from a hermeneutical approach, see Krzysztof Sonek, Truth, Benty, and Goodness in Biblical Narratives: A Hermenentical Study of Genesis 21:1-21, Beihefte zur Zeitschrift für die alttestamentliche Wissenschaft 395, Berlin-New York, 2009.

${ }^{20}$ On the traditional etymons attributed to the proper names Hagar and Ismael, see $A$ list of the proper names occuring in the Old Testament with their interpretations principally compiled from Simonis and Gesenius, London, 1850, pp. 36 and 65, respectively.

${ }^{21}$ Robert S. Kawashima, Biblical Narrative and the Death of the Rhapsode, Bloomington-Indianapolis, 2004, p. 37. 
in which the iconographic element-of a profoundly domestic nature-dominates the action from beginning to end.

Thus, we are told that the preparations for departure take place at dawn: "So Abraham rose early in the morning" (wayyashkem 'A (wayyiqqah-lehem wẹhèmath mayim wayyittèn 'el-Hägär), ${ }^{22}$ items recalling a semi-nomadic setting. Yet a waterskin (so in Sa' adyah: qirbat $m \vec{a}$ ), ${ }^{23}$ often made of an old goatskin, could hold no more than fifteen litres of water, very little for a mother and child making a long journey across the desert. Was Abraham perhaps giving them provisions for a shorter trip? A similar idea can be inferred from the apocryphal Ethiopic text of the 'Book of Jubilees', which tells us that Abraham gave her a bottle of water (wazeq mäye) ${ }^{24}$ for the journey, clearly suggesting a shorter distance. In his Antiquitates, Josephus also reports that Abraham provided Hagar with a bottle of water, even though he later notes that she and Ismael were banished "to some distant country". 25 Abraham places these provisions on Hagar's shoulder, hands over her son, and takes his

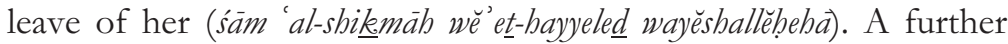
argument in support of a short journey is supplied by the fact that ancient law, as transmitted by the Nuzi texts (2nd half of the 15th c. BC) prohibited the banishment of a bondswoman and her child, ${ }^{26}$ thus accounting for Abraham's doubts in Gn 21:11: “The

22 MSS Sinaiticus Arabic 2 (ca. 10 c. A.D., fol. 30r) and Sinaiticus Arabic 4 (ca. $10^{\text {th }}$ c. A.D., fol. $22 \mathrm{v}$ in the margin) read: fa-akhada (Abraham) kbubzan wa-siqa min ma ("he [Abraham] took bread and a skin of water"). For the dating of these two MSS, cf. Aziz S. Atiya, The Arabic Manuscripts of Mount Sinai, Baltimore, 1955, p. 3 (n. 2, 4).

${ }^{23}$ Cf. J. Derenbourg (ed.), CEuvres complètes de R. Saadia ben Iosef alFayyoûmî. Version árabe du Pentateuque, revue, corrigée et accompagnée des notes hébraïques avec quelques fragments de traduction française d'après l'arabe, Paris, 1893, p. 31. Cf. Aramaic bèmath, A. Tal, A Dictionary of Samaritan Aramaic, 2 vols., Leiden, 2000, I, p. 282.

24 The Book of Jubilees, edited and translated by James C. Vaderkam, 2 vols., Louvain, 1989, I, p. 100 (Ethiopic text), II, p. 104 (Eng. trans.).

25 Josephus, Antiquitates Iudaeorum I,12,3 (ed. by H. St. J. Thakeray, Cambridge, Mass.1967 = 1930).

${ }^{26}$ John Bright, A History of Israel, Bilbao, 1970 (7th ed. corrected and augmented), p. 95 (Spanish trans.). 
matter was very distressing to Abraham on account of his son"

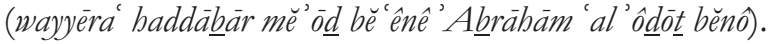

The picture conjured up in Gn 21:14 was clearly intended to shock, to arouse in the reader-or in the audience-a sensation that would have been greatly diluted by the inclusion of dialogue. This is heightened by the actual departure of Hagar and the boy, in which the author seeks a kind of narrative perspective with which to capture the image: "And she departed, and wandered about in

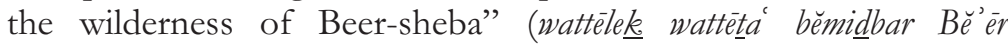
Shäba). He achieves this in masterly fashion with the closing coordinate clause, but more particularly with the verb form têtá, i.e. "she wandered", suggesting that Hagar and her son were lost, uncertain where to head for in the Negev plain — an area well suited for semi-nomadic living - as is evident in the expression "in the

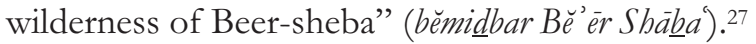

The redactor provides us here with some fascinating chronological information, in using the term yeled ("boy") to describe Ismael. The Hebrew yeled is a cognate of the Arabic walad, ${ }^{28}$ both connected with the Assyrian etymon wa-al-du. ${ }^{29}$ The question of Ismael's age is an interesting one, for though the narrator considers him a small boy (yele $\underline{\text { d) }}$, whose mother places him

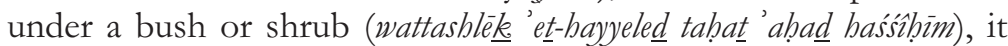
must be assumed that he was over fourteen years old (cf. Gn 16,16; $21,5)$, since the angel explicitly instructs her to take Ismael by the

${ }^{27}$ M. Cogan, "Beer-sheba", in Paul J. Achtemeier (ed.), HarperCollins Bible Dictionary, New York, 1996 (2 ${ }^{\text {nd }}$ ed.), p. 111. Cf. George Armstrong, Names and Places in the Old and New Testament and Apocrypha with their Modern Identifications, London: Published for the Committee of the Palestine Exploration Fund by A.P. Watt, 1889, p. 25.

28 Wilhelm Gesenius, Thesavrus philologicus criticus lingvae hebraeae et chaldaeae Veteris Testamenti, Leipzig, 1840, II, p. 595. On the value of this root in Targum Onkelos, see Edward M. Cook, A Glossary of Targum Onkelos, according to Alexander Sperber's Edition, Leiden-Boston, 2008, p. 115.

29 The Assyrian Dictionary (CAD), ed.-in-charge A. Leo Oppenheim, Chicago, Il.: The Oriental Institute, 1964, I, pp. 287ff. Cf. Ignace J. Gelb, Glossary of Old Akkadian, Chicago, Il.: The Oriental Institute, 1957, p. 38, and Wolfram von Soden, Akkadisches Handwörterbuch, 3 vols., Wiesbaden, 1965, 1972, 1981, III, pp. 1457-1459. 
hand (Gn 21:18), suggesting that he was old enough to walk. This was the interpretation favoured by Saint Jerome, who notes that "quando Isaac natus est, XIII annorum erat Ismael".30 What follows is well known: with God's help, Hagar saw a fountain, which saved her life and that of her son; then Ismael dwelt in the wilderness of Paran, near Egypt (Gen 21:21) and became an expert bowman (Gn 21:20). ${ }^{31}$

\section{THE 'TEXT' AND OTHER POSSIBLE FORERUNNERS}

As suggested earlier, the fact that Eutychius devotes so little space to the reason for the banishing of Hagar and Ismael is not in itself surprising. Indeed, when dealing with Abraham in his Chronography, Bar Hebraeus makes no reference at all to the incident. ${ }^{32}$ The same is true of Me'arath Gazzē, which offers no information in this respect. ${ }^{33}$ The scanty treatment of the event in the Christian chronographies may perhaps be due to Paul's commentaries on the passage, as in Gal 4:22-31, which concludes (vv. 30-31): "But what does the scripture say? 'Drive out the slave and her child; for the child of the slave will not share the inheritance with the child of the free woman'. So then, friends, we are children, not of the slave but

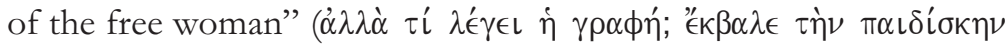

30 'Hebraicae qvaestiones in Libro Geneseos' ad 21:14, in S. Hieronymi presbyteri opera. Pars I. Opera exegetica, Turnhout, 1959, pp. 24-25.

${ }^{31}$ MS Sinaiticus Arabic 4 (ca. $10^{\text {th }}$ c. A.D.), fol. $22 \mathrm{v}$, says that Ismael learned the technique from the archers in this desert, cf. wa-kana yata allamu al-ramy fi tilk al-barriyyah. MS Sinaitic Arabic 2 (ca. $10^{\text {th }}$ c. A.D.) omits this information, cf. fols. 30r-v. Sa adyah rendered: wa-kāna rämi ("he was a bowman"), cf. J. Derenbourg (ed.), CEuvres complètes de R. Saadia ben Iosef al-Fayyoûmî. Version árabe du Pentateuque, p. 31.

32 Bar Hebraeus, The Chronography of Gregory Abûl Faraj, being the first part of his political history of the world, ed. and trans. Ernest A. Wallis Budge, Piscataway, NJ, 2003 (= Oxford, 1932), pp. 4r-4v (Syriac), 10-11 (Engl. trans.).

33 Carl Bezold, Die Schatzhöble, aus dem syrischen Texte, dreier unedirten Handschriften, Leipzig: J.C. Hinrichs'sche Buchhandlung, 1883, pp. 144-156 (Syriac text), 35-37 (German trans.). Cf. its Arabic recension in Margaret Dunlop Gibson, Apocrypha Arabica, edited and translated into English, Studia Sinaitica VIII, London: C.J. Clay and Sons, 1901, pp. 37-39 (Arabic text), 39-41 (English trans.). 


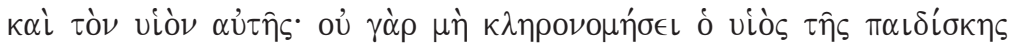

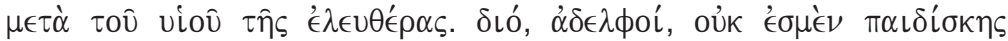

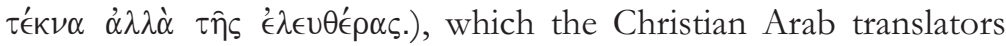
conveyed in Arabic through their rendering of the Pauline letters. ${ }^{34}$

This rejection of Hagar and Ismael, which derives from the traditional Jewish interpretation, was clearly perceptible in both the Christian $^{35}$ and Islamic contexts. ${ }^{36}$ In the Syriac work entitled 'The Book of the Himyarites', which narrates the events of the massacre of the Christians in the South-Arabian city of Nağrān, its author briefly alluded to this negative perception of Hagar, and consequently of her son Ismael. ${ }^{37}$ On its part, in the Islamic setting, it gave rise to an interesting narrative development of the reason, largely intended to counter the version transmitted by Jewish postbiblical literature. ${ }^{38}$ Even so, despite the importance of the figure of Abraham and his milieu, ${ }^{39}$ Muslim authors paid a varying degree of

${ }^{34}$ Cf. M. Dunlop Gibson, An Arabic version of the epistles of St Paul to the Romans, Corinthians, Galatians, with part of the Epistle to the Ephesians from a ninth century MS. in the convent of St Catharine on Mount Sinai, London, 1894, p. 106.

35 Gerbern S. Oegema, "The Pseudepigrapha and the Narratives in Luke-Acts", in G. S. Oegema \& James H. Charlesworth (eds.), The Pseudepigrapha and Christian Origins: Essays from the Studiorum Novi Testamenti Societas, New York-London: T\&T Clark, 2008, p. 155.

36 Cf. Sidney H. Griffith, The Church in the Shadow of the Mosque: Christians and Muslims in the World of Islam, Princeton-Oxford, 2008, p. 24, n. 6 .

37 Axel Moberg, The Book of the Himyarites. Fragments of a Hitherto Unknown Syriac Work, edited, with introduction and translation, with eight facsimiles, Lund: C.W.K. Gleerup, 1924, p. cxliii (ch. 49).

38 See on this issue, M. Ohana, "La polémique judéo islamique et l'image d'Ismaël dans Targum Pseudo-Jonathan et dans Pirke de Rabbi Eliezer", Augustinianum 15 (1975), pp. 367-387. Based on targumic materials, M. Pérez Fernández, "La tradición targúmica de Agar e Ismael", Miscelánea de Estudios Árabes y Hebraicos 49 (2000), pp. 87-103 (Festschrift Prof. Antonio Torres Fernández).

39 Cf. Gustav Weil, Biblische Legenden der Muselmänner, Frankfurt am Main: J. Rütten, 1845, pp. 68-99; D. Sidersky, Les origines des légendes musulmanes dans le Coran et dans les vies des prophètes, Paris: Librairie orientaliste Paul Geuthner, 1933, pp. 31-54. For specific stories, see Comte Du Mesnil du Buisson, "Trois histoires arabes sur Abraham et 
attention to the event narrated in Gn 21:14-16, to judge by the sources..$^{40} \mathrm{Ibn} \mathrm{Sa}$ d, for example, has nothing to say about it, ${ }^{41}$ while the chronicler Ibn al-Athīr offers a narrative treatment of the reasons for the banishment, which appears to draw on a number of traditions that eventually merged to form a single text. ${ }^{42}$

In fact, the construction placed on the passages in Gn 21:8-21 by $\mathrm{Paul}^{43}$, reflecting the traditional Jewish interpretation, is the most likely explanation for the fact that most Antiochene Greek commentators make no reference to the banishment of Hagar and Ismael. Their attitude appears to reflect the self-ascribed supremacy of Christianity over Judaism. ${ }^{44}$ For this reason, not only did the Pauline interpretation fail to prevail, but the official Jewish interpretation of the incident was discredited, thus prompting a greater freedom both in the historical reading of the Book of Genesis and in its exegesis by Christian authors on the basis of the various materials making up the book. Clearly, even though

Moïse”, Revue des Études Juives 99 (1934), pp. 119-126; J. Finkel, “An Arabic story of Abraham”, Hebrew Union College Annual 12-13 (1938), pp. 387-409; C. Snouck-Hurgronje, "La légende qorânique d'Abraham et la politique religieuse du Prophète Mohammed", Revue Africaine 95 (1951), pp. 273-288 (translated with an introduction by G.H. Bousquet); A. Guthrie, "The significance of Abraham", The Muslim World 45 (1955), pp. 113-120.

40 Cf. D. Sidersky, Les origines des légendes musulmanes, p. 51. Islamic narratives about Hagar and Ismael have been analysed by C. Castillo, "Abraham, Agar e Ismael en la tradición musulmana", Ámbitos. Revista de Estudios de Ciencias Sociales y Humanidades 18 (2007), pp. 11-15. Cf. Enno Litmann, "Ein islamisches Heiligenlied auf Hagar und Ismael", Die Welt des Islams 23 (1941), pp. 156-169; Reuven Firestone, Journeys in Holy Lands: the evolution of the Abraham-Ismael legends in Islamic exegesis, Albany, NJ, 1990. On Ismael, H. Schmid, "Ismael im Alten Testament und im Koran", Judaica 32 (1976), pp. 76-81 and 119-129.

${ }^{41}$ Cf. Ibn Sa'd, al-Ṭabaqāt al-Kubrā, Beirut, s.d., I, pp. 46-52.

${ }^{42}$ Ibn al-Athīr, al-Kämil fì l-tả rikeh, Beirut, s.d., I, p. 59.

43 Cf. Gal 4:21-31; Rom 9:6-9; 10-13. Cf. M. Dunlop Gibson, An Arabic version of the epistles of St Paul, pp. 106 and 20 respectively.

44 Lucas Van Rompay, "Antiochene Biblical Interpretation: Greek and Syriac", in J. Frishman \& L. Van Rompay (eds.), The Book of Genesis in Jewish and Oriental Christian Interpretation: A Collection of Esssays, Louvain, 1997, p. 121. 
contacts between Jews and Christians in an exclusively Arab setting date from the pre-Islamic period, ${ }^{45}$ those contacts subsequently diminished, for various reasons, in the Arab milieu.

Yet the Antiochene Greek exegetes were not alone in ignoring the incident; though the literary sagas that grew up around the figure of Abraham naturally aroused interest among Syrian and Arab authors, ${ }^{46}$ the Syrian chroniclers make no reference to the episode: even the celebrated 'Chronicle' of Michael is silent on the event. ${ }^{47}$ It is hardly surprising, therefore, that the Christian chroniclers writing in Arabic are not much more enlightening than their Muslim counterparts. For example, the tenth-century Melkite chronicler Agapius of Menbij (Mahbūb al-Manbijī), in his Kitāb al'Unwān, does not even allude to the banishing of Hagar and Ismael. 48

Mahbūb al-Manbijî̀s work is of particular interest, since it includes a certain amount of information on Ismael as the father of the Arab peoples. We are told, for example, that since Hagar begat Ismael, his children were known as the children of Hagar (Banù

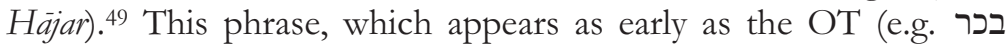
בני ישמעאל) Gn 25:16) and in Qumrān בני ישמעאל Gn:13 בישמל 1QM II = 4Q494, col. II,13; sg. בר ישמעאל 4Q551 4QdanSuz? ar, frag. 1,3), 50 is linked to the Syriac mĕhaggĕrayye (which gave rise to the Arabic mubägüirün), most likely derived from the Greek oi'A $\gamma \alpha \rho \eta$ vor,

45 Yury Arzhanov, "Zeugnisse über Kontakte zwischen Juden und Christen im vorislamischen Arabien”, Oriens Christianus 92 (2008), pp. 79_ 93.

46 S. P. Brock \& Simon Hopkins, "A Verse Homily on Abraham and Sarah in Egypt Syriac Original with Early Arabic Translation”, Le Muséon 105:1-2 (1992), pp. 87-146.

${ }^{47}$ Chronique de Michel le Syrien, patriarche jacobite d'Antioche (1166-1199), editée pour la première fois et traduit en français par J.-B. Chabot, 3 vols., Paris, 1899, I, pp. 33-34 (III,1).

${ }^{48}$ Cf. Alexandre Vasiliev, "Kitab al- 'Unvan. Histoire universelle écrite par Agapius (Mahboub) de Menbidj. Partie I”, Patrologia Orientalis V, Paris, 1910, pp. 661-666.

49 Cf. A. Vasiliev, "Kitab al-'Unvan...", Patrologia Orientalis V, Paris, 1910, pp. 662-663.

50 The Dead Sea Scrolls Study Edition, ed. by Florentino García Martínez \& Eibert J.C. Tigchelaar, Leiden-New York-Köln: Brill, 1999, pp. 116-117, 1102-1103. 
which initially had the meaning of 'Arabs', but was later used to refer to 'Muslims'. ${ }^{51}$

Similarly, he informs us - as do other Arabic sources ${ }^{52}$ - that Ismael's children were called 'Arabs' because he mixed with the Jurhum tribe, marrying women of that tribe and speaking Arabic (wa-samü aydan al-'arab min sabab mukhälatah Isma'il qawm Jurbum waliannahu tazawajja minhum al-nisä wa-liannahu takallama bi-l-arabiyyah ${ }^{53}$ and also "Ishmailis" because their father was Ismael (wa-samù ismätiliyyin min Ismâtil abihim); ${ }^{54}$ this provides a link to the expression

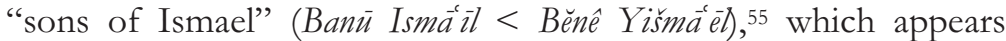
twice in the OT (1 Chr 1:28.31) and also occurs in the OT apocrypha as a synonym for 'Arabs' (cf. Jub[et] 20:13).56 The matronymic expression "sons of Hagar" (awläd Häjar) was also

51 S.H. Griffith, "The Prophet Muhammad", in Toufic Fahd (ed.), La vie du Prophète Mahomet: Colloque de Strasbourg, 1980, Paris: Presses Universitaires de France, 1983, pp. 122-123. Cf. The Seventh Century in the West-Syrian Chronicles, introduced, translated and annotated by Andrew Palmer, including two seventh-century Syriac apocalyptic texts introduced, translated and annotated by Sebastian Brock, with added annotation and an historical introduction by Robert Hoyland, Liverpool, Liverpool University Press, 1993, pp. 49, n. 163 and 144.

52 Ibn Kathīr, al-Bidāyah wa-l-nihāyah, ed. 'Alī Muhammad Mu'awwaḍ and 'Ādil Muhammad 'Abd al-Mawjūd, Beirut, 1415 H./1994 A.D., I, pp. $177-178$.

53 Ibn Kathīr, al-Bidāyah wa-l-nihāyah, I, p. 178 records that he was the first who spoke "a pure and eloquent Arabic" (al-arabiyyah al-fașīhah albalighah). On the linguistic situation in pre-Islamic Arabia, see M.C.A. Macdonald, "Reflections on the linguistic map of pre-Islamic Arabia”, Arabian Archaeology and Epigraphy 11 (2000), pp. 28-79. 663.

${ }^{54}$ Cf. A. Vasiliev, "Kitab al-'Unvan I", Patrologia Orientalis V, pp. 662-

55 On this naming, see Theresia Hainthaler, Christliche Araber vor dem Islam, Leuven-Paris-Dudley, Mass., 2007, pp. 15-18.

${ }^{56}$ The Ethiopic Version of the Hebrew Book of Jubilees otherwise known among the Greeks as $H$ AEITHH IENELIL, ed. R.H. Charles, "Anecdota Oxoniensia», Oxford: Clarendon Press, 1895, 72-73. On the term 'Arab' and its parallels through history, see I. Eph 'al, "'Ismael' and 'Arab(s)': a transformation of ethnological terms", Journal of Near Eastern Studies 35 (1976), pp. 225-235; cf. Jan Retsö, The Arabs in Antiquity. Their history from the Assyrians to the Umayyads, London-New York: Routledge, 2003. 
current amongst Arab tribes, and is used in a number of textual sources to refer to the South Arabian branch of the sons of Ismael, as distinct from the Northern Arabs. ${ }^{57}$ It should be noted that the earliest Syriac colophon using a date formula by "the mĕhaggéràyé, children on Ish[mael], the son of Hagar" is BL Add. 14, 666, an East Syriac NT of AD 682.58

Underlying these two elements, whose roots lie deep in the biblical text, the relationship between Ismael and the Jurhum tribe-his marriage to their women, his adoption of the Arabic language - is a clear reference to a nomadic lifestyle. The modus vivendi of this non-sedentary group led, as in other cases, ${ }^{59}$ to Ismael and his descendants being seen as 'uncivilised' nomads. Yet in making no reference to the banishment episode, the author adopts the Christian approach.

Naturally enough, however, references to the incident are to be found in the commentaries on the books of the Bible, even though these offer little more than a paraphrase of the biblical text, with no further details. This is the case, for example, of the only commentary in Arabic on the OT, Kitāb firdaws al-nașañiyya, composed by the East Syrian Abū l-Faraj 'Abdallāh ibn al-Ṭayyib (d. 1043). ${ }^{60}$ In his commentary, whose source is Isho dad of Merv, ${ }^{61}$

57 Cf. Irfan Shahîd, Byzantium and he Arabs in the fifth century, Washington D.C.: Dumbarton Oaks, 1989, pp. 345-347, 385-390. Cf. J. Spencer Trimingham, Christianity and the Arabs in Pre-Islamic Times, Beirut: Librairie du Liban, 1979, pp. 10-11, n. 3.

58 Sebastian P. Brock, "The use of Hijra dating in Syriac manuscripts: a preliminary investigation", in J.J. van Ginkel, H.L. Murre-van den Berg \& T.M. van Lint (eds), Redefining Christian Identity. Cultural Interaction in the Middle East since the Rise of Islam, «Orientalia Lovaniensia Analecta»134, Leuven: Peeters, 2005, p. 278.

${ }^{59}$ Cf. Hans-Werner Fischer-Elfert, "Sedentarism and Nomadism as criteria of Ancient Egyptian Cultural Identity", in Stefan Leder \& Bernhard Streck (eds.), Shifts and Drifts in Nomad-Sedentary Relations, Wiesbaden, 2005, pp. 327-345.

60 On this 'Commentary', see Samir Khalil Samir, "Christian Arabic Literature”, in M.J.L. Young, J.D. Latham \& R.B. Serjeant (eds.), Religion, Learning and Sciencie in the 'Abbasid Period, Cambridge, 1990, p. 447.

${ }^{61}$ C. Molenberg, "Išo' bar Nun and Išo'dad of Merv on the book of Genesis: a study of their interrelationship", in J. Frishman \& L. Van Rompay (eds.), The Book of Genesis, pp. 197-228. For Isho'dad of Merw's 
Ibn al-Tayyib simply adds that the event was due not to Abraham's cruelty (qasäwatan), but rather to his desire not to upset Sarah, in view of what God had told him (wa-hattà là yühisha Sarā mámà qāla Allāh la-bu). ${ }^{62}$

Whilst this desire not to contradict Sarah is certainly hinted at in Gn 21:12, the phrase is enlarged upon in other works of Jewish origin; in the Ethiopic 'Book of Jubilees', for example, we read that God told Abraham: "Listen to everything that Sarah says to you and do (it)". ${ }^{63}$ This addition appears to be the result of prior exegesis based on the order given to Abraham by Sarah. In this text-in contrast to the Christian tradition - the story parallels the biblical text, which it follows with minor changes suggesting other sources.

This approach is shared by Josephus, who-though he notes that "As for Sarah, she at first loved Ismael, who was born of her own handmaid Hagar, with an affection not inferior to that of her own son"-eventually asserts that Sarah "therefore persuaded Abraham to send him and his mother to some distant country". ${ }^{64}$ However, Josephus introduces into his account a gloss which sheds considerable light on the problems that this passage must have posed for Jewish exegesis. Thus, following Gn 21:11, Josephus remarks that "at the first he (i.e. Abraham) did not agree to what Sarah was so zealous for and thought it an instance of the greatest barbarity to send away a young child and a woman unprovided of necessaries". ${ }^{65}$

Josephus argues that Abraham gave way to Sarah's demands, because God agreed. This position, characteristic of Jewish exegesis, is clearly supported by Gn $21: 12$, although surprisingly little attention is ever paid to Gn 21:13, where in reference to Ismael, God says: "as for the son of the slave woman, I will make a nation of him also, because he is your offspring" (wë-gam 'et-ben-

exegesis, see, Commentaire sur l'Ancien Testament. I. Genèse, ed. J.-M. Vosté \& C. van den Eynde, trans. C. van den Eynde, Louvain, 1950, 1955.

62 Ibn at-Taiyib, Commentaire sur la Genèse, ed. \& trans. by J.C.J. Sanders, Louvain, 1967, I, p. 76 (Arabic), II, p. 71 (French trans.).

${ }_{63}$ The Book of Jubilees, I, pp. 99-100 (Ethiopic text), II, p. 103 (Eng. trans.).

${ }^{64}$ Jos., Ant. I,12,3.

${ }^{65}$ Jos., Ant. I,12,3. 


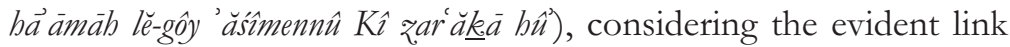
between this verse and Gn 21:17-18. ${ }^{66}$

In this context, it is apparent that the exegetes were to a large extent hostage to the redactor of the biblical text, who wove his account with great skill and with a thorough knowledge of the social setting in which the episode takes place. At the same time, he allowed into his narrative a modicum of social irony: Hagar is both Egyptian and a slave, and on both counts represents groups excluded from the ruling tribal élite. Thus, Hagar belongs to an ethnically and economically inferior group with no access to the hereditary control of the tribe, ${ }^{67}$ and more specifically to Abraham's inheritance. Yet God, whilst not contradicting Sarah's unjust order to Abraham, takes pity on the banished mother and child, as we are told in Gn 21:17ff., thus redressing the injustice narrated in Gn 21:10ff.

\section{THE 'INTERTEXT' AND ITS SOURCES}

In the introduction, we referred to the second part of the fragment as the "intertext", ${ }^{68}$ not because the text is not physically visible, but because the transmitted text includes others, as a result of what we have referred to in the title of this paper as 'intertextuality'. It combines various source referents which the author used in constructing his text. Let us recall the lines in questions:

$$
\begin{aligned}
& \text { و اخرجهُ مع امه الي ارض ينزب وارض اليمن فسكنها [...] }
\end{aligned}
$$

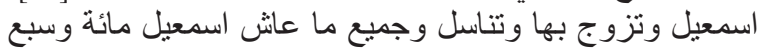

$$
\begin{aligned}
& \text { وتثلثون سنة }
\end{aligned}
$$

${ }^{66}$ R.N. Whybray, "Genesis", in John Barton \& John Muddiman, The Oxford Bible Commentary, Oxford, 2001, p. 53.

${ }^{67}$ Marie-Therese Wacker, "Feminist Criticism and related Aspects", in J.W. Rogerson \& J.M. Lieu, The Oxford Handbook of Biblical Studies, Oxford, 2006, p. 639.

${ }^{68}$ Cf. several examples of 'biblical' intertexts as given by Ulrich Luz, "Intertexts in the Gospel of Matthew", Harvard Theological Revue 97:2 (2004), pp. 119-137. 
At the outset, there is no apparent hiatus between what we have termed "text" and "intertext", since the sentence "and sent him with his mother to the land of ..." acts as a link between the two segments. In fact, although the whole text takes as its basis Gn 21:10-21 + 25:17a, the second part is the result of some textual interaction. This interaction, morever, is not an isolated phenomenon in Christian Arabic literature; rather, its component elements form part of a tradition which had a huge impact on Christian authors writing in the Arabic language.

In composing his text, as we shall see, Eutychius makes use of the apocalyptic tradition, whose influences date back to before the Christian era, indeed to around the $3^{\text {rd }}$ century BC. ${ }^{69}$ The apocalyptic tradition, with all the varied elements and motifs which shaped it over the centuries, ${ }^{70}$ was constantly revived throughout history, in the Byzantine milieu, ${ }^{71}$ in the Arab-Islamic world ${ }^{72}$ and in Syriac writings, ${ }^{73}$ whose historical effectivism endowed every one of these texts and their literary motifs with a unique value, depending on the ecclesiological setting and the period in question $;{ }^{74}$ topical references were often applied to the exegesis

69 R.H. Charles (ed.), The Apocrypha and Pseudepigrapha of the Old Testament, 2 vols., Oxford: Clarendon Press, 1913, II, viii.

70 Cf. J.P. Monferrer-Sala, "Tradición e intertextualidad en la apocalíptica cristiana oriental. El motivo de los reyes de Etiopía y Nubia en el 'Apocalipsis (árabe) del Ps. Atanasio' y sus testimonia apocalyptica', AlQantara XXXV:1 (2011) 199-228.

${ }^{71}$ Paul J. Alexander, The Byzantine Apocalpptic Tradition, ed. Dorothy de F. Abrahamse, Berkeley: University of California Press, 1985.

72 Soliman Bashear, "Apocalyptic and Other Materials on Early Muslim-Byzantine Wars: A Review of Arabic Sources," Journal of the Royal Asiatic Society (1991), 173-207.

73 Sebastian P. Brock, "Syriac Views of Emergent Islam," in G.H.A. Juynboll (ed.), Studies on the First Century of Islamic Society, Carbondale: Southern Illinois University Press, 1982, 9-21 (rep. in S.P. Brock, Syriac Perspectives on Late Antiquity, London: Variorum, 1984, VIII).

74 J.P. Monferrer Sala, "Tipología apocalíptica en la literatura árabe cristiana", in Montserrat Abumalham (coord.), Literatura árabe cristiana, Madrid, 2001, pp. 51-74. 
through which the authors sought to account for the historical episodes narrated in the texts. ${ }^{75}$

The first striking feature is that, while Gn 21:14b focusses on Hagar, Eutychius has opted to rewrite the story focussing on Ismael. Thus, while Gn 21:14b gives "and she departed, and wandered about in the wilderness of Beer-sheba" (wattelek wattéta

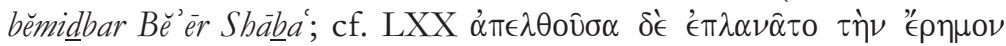

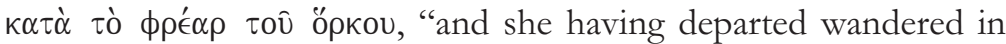
the wilderness near the well of the oath.”), Eutychius tells us that Abraham sent Ismael with his mother (akhraja-bu ma' ummi-hi). This is interesting not only in terms of the narrative involutio found in Eutychius' fragment, but also because to some extent a parallel is established with a recurring theme in the biblical narrative, in which women are rarely granted a vox narrationis. ${ }^{76}$

But Eutychius does not simply switch the protagonist of his account (Ismael instead of Hagar); he also introduces new elements drawn from a historiographical exegesis which, as we shall see, is shaped by the Eastern Christian apocalyptic tradition. ${ }^{77}$ We shall focus here on two of those elements, the toponyms Yatrib and alYaman. Both correspond to, or rather act as replacement concepts for, the term "desert" (midbar/éremos) used in Gn 21:14, even though Yatrib refers, strictly speaking, to the territory of what was to become Medina, ${ }^{78}$ while al-Yaman denotes a vast area that included not only dry lands but also irrigated fields and even

${ }^{75}$ Jan J. Van Ginkel, "The End is Near! Some Remarks on the Relationship between Historiography, Eschatology, and Apocalyptic Literature in the West-Syrian Tradition", in van Bekkum, Wout Jac. et al (eds.), Syriac Polemics. Studies in Honour of Gerrit Jan Reinink, Leuven-Paris Dudley, Ma: Peeters, 2007, pp. 206-217.

${ }^{76}$ Cf. S.P. Brock, "Creating women's voices: Sarah and Tamar in some Syriac narrative poems", in Emmanouela Grypeou \& Helen Spurling (eds.), The Exegetical Encounter between Jews and Christians in Late Antiquity, Leiden-Boston, 2009, pp. 125-141.

77 See for instance Gerrit J. Renink, "Ismael, der Wildesel in der Wüste. Zur Typologie der Apokalypse des Pseudo-Methodius", Byzantinische Zeitschrift 75 (1982), pp. 336-344.

78 Al-Ṭabarī, Tảrïkh al-rusul wa-l-mulük, ed. M.J. de Goeje, 16 vols., Leiden, 1964 (= 1897-1901), I, pp. 916-918. Cf. Leone Caetani, Studi di storia orientale. III, Milano, 1914, pp. 37-42. 
cities.79 The reason for this identification is to be found, as indicated earlier, in the Christian apocalyptic tradition, ${ }^{80}$ in which the 'children of Ismael' were seen as coming from the desert of Yatrib; in that tradition, the two elements are linked in a single phrase, as occurs for example in the 'Apocalypse of Ps.Methodius'. ${ }^{81}$

As used here, the toponym al-Yaman ${ }^{82}$ must be understood as a pars pro toto for South Arabia, which was moreover the land from which the Arabs were believed to originate, and in which the Muslim chroniclers placed the Jurhum tribe. ${ }^{83}$ A certain Christian apocalyptic tradition holds that the territory of Yemen, ${ }^{84}$ i.e. South Arabia, will come under Ethiopian rule. This notion is the result of a teleological process of restitution of the true Christian faith, which must begin with the capture of the territory in which the Arabs originated, i.e. Yemen or Arabia Felix; ${ }^{85}$ this is reflected in

${ }^{79}$ Robert G. Hoyland, Arabia and the Arabs. From the Bronze Age to the coming of Islam, London-New York, 2002, pp. 36-57, with a selected bibliography in pp. 275-280.

80 This idea is found in other genres, including martyrdoms, cf. Christa Müller-Kessler \& Michael Sokoloff, The Forty Martyrs of the Sinai Desert, Eulogios, the Stone-Cutter, and Anastasia, A Corpus of Christian Palestinian Aramaic III, Gröningen: Styx, 1996 p. 13.

${ }^{81}$ F.J. Martínez, Eastern Christian Apocalyptic in the Early Muslim Period, XI.1 (pp. 77 Syriac text, and 139 Eng. trans.). Cf. J.P. Monferrer-Sala, "Sacred readings, lexicographic soundings: cosmology, men, asses and gods in the Semitic Orient”, in J. P. Monferrer Sala \& Á. Urbán (eds.), Sacred Text: Explorations in Lexicography, Frankfurt am Main: Peter Lang, 2009, p. 208.

${ }^{82}$ Cf. Noha Sadek, "Yemen", in Josef W. Meri (ed.), Medeval Islamic Civilization: An Encyclopedia, New York-London, 2006, I, pp. 870-872.

${ }^{83}$ Ibn Kathīr, al-Bidāyah wa-l-nihayyah, I, p. 178. On the assumption that the Arab nomad originated in the Arabian Peninsula, see M.C.A. Macdonald, "Arabi, Arabie e Greci. Forme di contatto e percezione", in S. Settis (ed.), I Greci. Storia, cultura, arte, società. III: I Greci oltre la Grecia, Torino, 2001, pp. 231-266.

${ }^{84}$ J. Ziadé, "Un Testament de N.-S.", Revue de l'Orient Chrétien 21 (1918-19), 267.), which is obviously a mistake for ard al-Yaman.

${ }^{85}$ On this, see Jean-François Breton, Arabia Felix from the Time of the Queen of Sheba, Eighth Century B.C. to First Century A.D., translated by A. LaFarge, Notre Dame, Ind.: University of Notre Dame Press, 1999. 
the occupation of the territory by the kings of Nubia and/or Ethiopia in an apocalyptic tradition represented by the 'Apocalypse of Ps.-Athanasius'. Clearly, this location of Ismael-whom Eutychius places in Arabia in order to link Ismael with the origin of the Arabs and of Islam- ${ }^{86}$ does not coincide with the Bible account, since the eponym of these tribes suggests that both they and their descendants were clearly linked to the desert regions lying between Palestine and Egypt, and to the tribes inhabiting that area, the Amalekites and the Midianites. ${ }^{87}$

The three coordinate clauses that follow, fa-sakana-hä Ismätil watazawajja bi-hà wa-tanäsala ("and he dwelled and married there and he multiplied") are of course an allusion to the settling of Ismael and his progeny in South Arabia, which serves to reassert the idea that South Arabia was the birthplace of Ismael's descendants and thus of the Arabs. However, at the same time, Eutychius again provides a recasting of $\mathrm{Gn} 21: 21$, which has Ismael dwelling not in

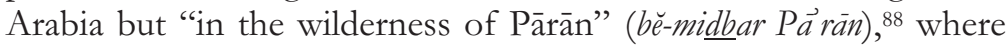
"his mother got a wife for him from the land of Egypt" (wattiqqahlô 'immô 'ishshäh méeres misrāyim), ${ }^{89}$ interpreted in LXX as à

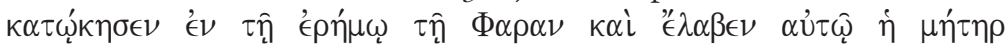

On the changing meanings of the phrase Arabia Felix, see Jan Retsö, "Where and what was Arabia Felix?", in Proceedings of the Seminar for Arabian Studies 30 (2000), 189-192.

86 Cf. Fergus Millar, "Hagar, Ismael, Josephus and the origins of Islam", Journal of Jewish Studies 44:1 (1993), pp. 23-45.

${ }^{87}$ I. Eph'al, The Ancient Arabs: Nomads on the Borders of the Fertile Crescent $9^{\text {th }}-5^{\text {th }}$ Centuries B.C., Jerusalem-Leiden, 1982, pp. 234-240. See also J. Retsö, The Arabs in Antiquity, pp. 222-228. Cf. D. Sidersky, Les origines des légendes musulmanes, pp. 51-53.

88 So in MSS Sinaiticus Arabic 2 (ca. 10th c. A.D., fol. 30r) and Sinaiticus Arabic 4 (ca. $10^{\text {th }}$ c. A.D., fol. 22v) which render: barriyat Färān. The same translation is attested in Sa adyah, cf. J. Derenbourg (ed.), Euvres complètes de R. Saadia ben Iosef al-Fayyoûmî. Version árabe du Pentateuque, p. 31.

${ }^{89}$ MS Sinaiticus Arabic 4 (ca. 10 ${ }^{\text {th }}$ c. A.D., fol. 22v) gathers: qawwajatbu ummu-bu imra'atan min abl Miṣr, cf. MS Sinaitic Arabic 2 (ca. 10th c. A.D. fol. 30v): ankahat-bu ummu-bu imra'atan min abl Miṣr. A slightly-changed rendering is attested in Sa'adyah: wa-ittakhadat la-bu ummu-bu zawjat min balad Mișr, cf. J. Derenbourg (ed.), CEuvres complètes de R. Saadia ben Iosef alFayyoûmî. Version árabe du Pentatenque, 31. 


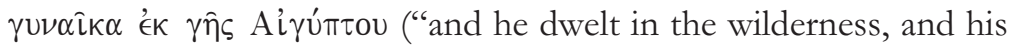
mother took him a wife out of Pharan of Egypt").90 Perhaps, as some sources appear to indicate, this story serves as background for the placing of some archers associated with the desert of Paran; ${ }^{91}$ the bowmen of Qedar (i.e. Arabs) are specially mentioned in the OT, ${ }^{92}$ since they played an important role in ancient Near Eastern warfare. ${ }^{93}$ At the same time, all the evidence suggests that

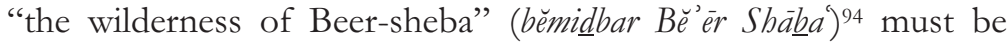
placed in the desert of Paran, which appears in a number of texts in connection with Qadesh, ${ }^{95}$ to the south of the Negev ("dry, parched, south country" in Hebrew) in the desert of Paran;96 this is

90 The Syriac version of the Peshittā follows the Hebrew text: hasa

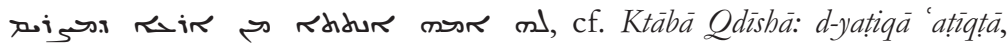
London: Trinitarian Bible Society, 1923, p. 12.

${ }^{91}$ Ismael is described as rôbeh qashshät in Gn 21:20.

92 A.E. Shipley—Stanley A. Cook, "Weapons", in T.K. Cheyne \& J. Sutherland Black (eds.), Encyclopadia Biblica: A Critical Dictionary of the Literary, Political and Religious History, The Archaology, Geography and Natural History of the Bible, 4 vols., London, 1899-1903, IV, col. 5275.

93 The Itureans, whose pater eponymus is Yețūr, one of the sons of Ismael (Gn 25:15; cf. 1 Ch 5:19), are described by the Greek chroniclers as Arabs who are excellent archers, cf. Strabo, The Geography, ed. with an English translation by H.L. Jones, London-Cambridge, Mass., 1960 1969, XVI, 218-19.

94 Volkmar Fritz, "Der Beitrag der Archäeologie zur historischen Topographie Palästinas am Beispiel von Ziklag", Zeitschrift der deutschen Palästina Vereins 106 (1990), pp. 78-86; cf. Idem, "Die Grenzen Landes Israel", in G. Galil \& M. Weinfield (eds.), Studies in Historical Geography \& Biblical Historiography Presented to Zecharia Kallai, «Supplements to Vetus Testamentum» 81, Leiden-Boston-Köln, 2000, pp. 14-15.

95 About Qadesh (Qädesh), cf. T.K. Cheyne, "Kadesh", in T.K. Cheyne \& J. Sutherland Black (eds.), Encyclopadia Biblica, II, cols. 2649-2652; Steven Breck Reid, "Kadesh", in P.J. Achteimer (ed.), Bible Dictionary, New York, 1996 (rev. ed.), p. 562.

${ }^{96} \mathrm{~J}$. Retsö, The Arabs in Antiquity, p. 223. On the geographical term Negev, see T.K. Cheyne, "Negeb", in T.K. Cheyne \& J. Sutherland Black (eds.), Encyclopadia Biblica, III, cols. 3374-3380. For the location of the desert of Paran, see Adrian Curtis, Oxford Bible Atlas, Oxford, 2007 ( $4^{\text {th }}$ ed.), map between pp. 77-78. Obviously, the identification of Biblical Pā rān (Arabized as Fārān) with one of the names of Makkah by Muslim 
borne out by the fact that Hagar is described as "Egyptian" (mișrît). ${ }^{97}$

Finally, the last sentence of the fragment (wa-jami $m \bar{a}$ ' $\bar{s} h \mathrm{~s} a$ Ismátil mi ah wa-sab" wa-talatüna sanah, "the whole time Ismael lived was one hundred and thirty seven years"), is an adaptation of Gn 25:17a, corresponding to the calculation found in Islamic Arabic sources. ${ }^{98}$ Interestingly, Eutychius opens and closes the fragment using the unmodified biblical text. In doing so, the author not only achieves a rounded narrative structure but also introduces an interesting determing factor: he achieves a high degree of authority by adducing the support of the biblical text for the information he provides. In other words, Eutychius makes use of the story narrated in the biblical text to introduce a number of additional elements that he deems appropriate, rewriting the text itself and taking full advantage of a textual interaction involving the apocalyptic and historiographical tradition of the Eastern Christian authors.

\section{CONCLUSION}

A number of conclusions can be drawn from this brief extract from Eutychius' Annals. First, it is representative of the 'attitude of silence' adopted by Christian authors with regard to the banishment of Hagar and Ismael, an attitude evident in the work of the greatest Christian commentator, Saint Jerome, who reports the incident without even mentioning Sarah's attitude. Indeed, he limits his commentary on Gn 21:14 to a discussion of Ismael's probable age when he and his mother Hagar were exiled..$^{99}$

Secondly, we are struck by the skill with which Eutychius composed this text; taking advantage of the auctoritas conferred by the biblical text, he succeeds in introducing-through an intertextual approach-elements from the mediaeval Christian

geographers does make no sense, cf. Yāqūt al-Hamawī, Mưjam al-buldān, 5 vols., Beirut, 1399 H./1979 A.D., IV, 225.

${ }^{97} \mathrm{~J}$. Retsö, The Arabs in Antiquity, p. 224.

98 For instance Ibn Kathīr, al-Bidāyah wa-l-nihäyah, I, p. 178. On the measuring time in Antiquity and some related questions, see Robert Hanna, Time in Antiquity, London-New York, 2009, pp. 96-115.

99 Cf. 'Hebraicae quaestiones in Libro Geneseos' ad 21:14, in S. Hieronymi prebyteri opera. Pars I. Opera exegetica, pp. 24-25. 
tradition, which circulated widely during the Ummayad and Abbasid periods. These elements, in the form of testimonia, were extensively disseminated through the apocalyptic and historiogaphical textual traditions, being adapted as they are hereto meet specific circumstances. Eutychius, like the Bible narrative, opts for a summarised account, with no added descriptive paraphrases or ad hoc exegesis; this suggests that the target audience was familiar with the mechanisms of the text and with the elements comprising the story of the banishment of Hagar and Ismael.

A number of points can thus be appreciated. First, and within the framework of the textual diachrony of the Genesis account, 100 the text produced by the biblical redactor of the saga that grew up around the figure of Ismael-and more specifically the episode of the banishing of Hagar and Ismael from the house of Abraham-is followed almost literally, except for a few changes, in the targûmin. ${ }^{101}$ Yet this narrative, for which—given the characteristics of the basic OT text-one might assume a flourishing literary tradition, is accorded little or no attention by Eutychius, who summarises it in just a few sentences.

Eutychius' fragment may thus be the result of a synthetic approach, given the vast amount of information he was obliged to include in small doses when constructing his work. At first glance, this would appear to be the logical explanation. Yet this still seems unlikely, given that Eutychius was writing at a time when CoptoArabic texts were being shaped as part of the 'first phase' of that major movement towards the conformation of the Coptic heritage in Arabic, undertaken by Coptic Arab authors ${ }^{102}$. Following the edict issued by the prefect 'Abdallāh b. 'Abd al-Malik in $698 \mathrm{CE}$, which imposed Arabic as the administrative language of the new

100 Cf. William M. Schniedewind, How the Bible Became a Book. The Textualization of Ancient Israel, Cambridge, 2004, pp. 19-23.

101 Cf. The Bible in Aramaic based on Old Manuscripts and Printed Texts, edited by Alexander Sperber, Leiden-Boston, 2004 ( $3^{\text {rd }}$ imp.), p. 30 (1209); Targum Palaestinense in Pentateuchum. Additur Targum Psudojonatan ejusque hispanica versio. L1. Genesis, dir. Alejandro Díez Macho, «Biblia Polyglotta Matritensia» Series IV, Madrid, 1988, pp. 118-121.

102 Samuel Rubenson, "Translating the Tradition: Some Remarks on the Arabization of the patristic Heritage in Egypt", Medieval Encounters 2:1 (1996), pp. 5-8. 
state, but above all after the drastic prohibition of Greek by Caliph al-Walid I in $715 \mathrm{CE}$, the Arabic language was readily adopted by Copto-Arabic authors; this hastened both the virtual demise of Greek as a spoken language ${ }^{103}$ and the progressive isolation of Coptic. ${ }^{104}$

Thus, Eutychius' work was clearly the result of a growing Arabisation - in terms both of quality and quantity; at the same time, Eutychius himself was a profoundly Arabised author, in the sense that he displayed not only a perfect mastery of the Arabic language, but also considerable familiarity with Islamic culture, which was then a matter of social prestige amongst Arabized writers. ${ }^{105}$ Eutychius was evidently aware of the importance of the figure of Ismael in Arabic, and particularly Islamic, culture; he knew that the Arabs were descended from him, and must also have been familiar with the Islamic accounts concerning Ismael, and specifically with the narration of Hagar and Ismael's expulsion.

Yet we should not immediately assume that this new cultural Arabization among Copto-Arabic authors in general, which had a particularly marked impact on Eutychius, offers an explanation of Eutychius' text on the banishing of Hagar and Ismael. Quite the contrary: the text is the result of a genuinely Christian tradition, which-fostered by the new political and religious situation in the Middle East in general and particularly in Egypt-embraced narrative elements reflecting the new Arabic reality and the resulting new textual reality, adding new features to an episode which belongs to the literary sagas that grew up around the figure of Abraham.

103 MacCoull, L. S. B., "Three cultures under Arab rule: the fate of Coptic", Bulletin de la Société d'Archéologie Copte 27 (1985), 68.

104 Arietta Papaconstantinou, "«They shall speak the Arabic language and take pride in it»: Reconsidering the Fate of Coptic after the Arab Conquest", Le Muséon 120:3-4 (2007), pp. 273-299.

105 See for example J.P. Monferrer-Sala, "Egyptian major issues...", in J.P. Monferrer-Sala_-V. Christides_-Th. Papadopoullos (eds.), East and West, pp. 215-216. 
